\title{
Growing Global Demand for Cash
}

\author{
Sayuri Shirai ${ }^{1,2}$ \& Eric Alexander Sugandi ${ }^{1,3,4}$ \\ ${ }^{1}$ Asian Development Bank Institute, Tokyo, Japan \\ ${ }^{2}$ Faculty of Policy Management, Keio University, Tokyo, Japan \\ ${ }^{3}$ Graduate School of Asia Pacific Studies, Waseda University, Tokyo, Japan \\ ${ }^{4}$ Institut Kajian Strategis, Universitas Kebangsaan Republik Indonesia, Jakarta, Indonesia \\ Correspondence: Eric Alexander Sugandi, Asian Development Bank Institute, Kasumigaseki Building 8F, 3-2-5, \\ Kasumigaseki, Chiyoda-ku, Tokyo 100-6008, Japan.
}

Received: October 2, 2019

Accepted: November 19, 2019

Online Published: November 25, 2019

doi:10.5539/ibr.v12n12p74

URL: https://doi.org/10.5539/ibr.v12n12p74

\begin{abstract}
Demand for cash is generally known to be influenced by several factors-including transaction motive used for payment, opportunity cost, precautionary motive, and other motives (such as aging and demand from abroad). In recent years, cashless payment methods have increasingly become prevalent in the world through various conventional tools and innovative convenient financial services using mobile phones and smart phones. Nevertheless, cash in circulation has been rising in many economies, especially after the global financial crisis. This paper seeks to examine factors affecting cash in circulation for 22 economies for the period 2000-2018. It also investigated the movements of banknotes in circulation differentiated by denomination for seven economies whose data were available. The empirical analysis of this paper found that the opportunity cost proxied by the central bank policy rates and age-related variable were the two most important robust determinants for cash demand. Namely, cash demand tends to grow with a decline in the policy rates and with an advancement of aging.
\end{abstract}

Keywords: money demand, monetary policy, central bank

\section{JEL Classification: E41, E52, E58}

\section{Introduction}

Cash is a useful instrument for payment of goods and services and other transactions. Cash remains essential in many economies today and will likely remain relevant in the future, since cash is likely to be used often by the elderly and marginalized, low-income people. Cash becomes useful especially when natural disasters or military conflicts cause serious damage to communities and people's daily lives by generating power shortage and destruction of buildings and computer system. Thus, many central banks view that retaining some level of cash in the society could be useful, despite high cash-handling cost and prevalent cash-associated crimes.

Conceptually, cash is central bank-issued money. It is the safest, liquid payment and financial instruments for the public. Cash fulfills the following basic functions of money - that is; unit of account, means of exchange, and store of value. Cash is legal tender and an official medium of payment determined by the government through the passage of law that requires creditors to accept debt service payment in the legal tender. Cash is also used for public charges and taxes. For the public, cash remains an important means of payment, but it is increasingly being taken over by private sector-issued money, such as bank deposits and other cashless and contactless tools. Central bank-issued money consists not only of cash, but also reserve balances of financial institutions with a central bank. Cash and reserve balances constitute the liability of the balance sheets of a central bank.

Cash demand of the public is generally influenced by (1) transaction motive used for payment, (2) opportunity cost, (3) precautionary motive, and (4) other motives. Transaction motive reflects demand for cash used for payments of goods and services as well as other transactions, which is likely to strengthen with an expansion in economic activities (normally proxied with nominal gross domestic product (GDP)). The opportunity cost for holding cash is related to the financial return arising from the close substitutes of cash, such as retail deposit rates paid by commercial banks to the public or cost of holding credit cards and bank cards (such as annual fees charged for the card membership). Generally, cash utilization tends to decline as GDP per capita increases due to 
greater access to bank deposits, debit cards, credit cards, and other cashless payment instruments. Moreover, the higher the opportunity cost, the lower the demand for cash becomes. As a related indicator, inflation also influences cash demand. Low inflation means that the opportunity cost of holding cash is low since the value of cash remains stable. Precautionary motive reflects demand for cash among households and firms that tend to grow at the time of financial and economic crises and/or a sharp decline in risk appetite among investors. Moreover, firms may maintain some liquidity assets in the form of cash to ensure smooth business operations even in a normal period.

Other motives include aging, tax-saving purposes, informal or illegal activities, and cash demanded from abroad. Cash is prevalent in economies with a large share of elderly population due to the habits and affinity for using cash as compared with the economies with a small share of elderly population. Some elderly people stop using credit cards after retirement. Cash demand from abroad is large for the case of the United States given that the US dollar is the most important reserve currency, invoice currency used for international trade and debt issuance, vehicle currency used for various foreign exchange transactions, as well as safe haven currency. Also, an increase in frequent foreign tourists, businesspersons, and students may raise cash demand for foreign currencies, especially when the exchange rates are perceived to be favorable (Flannigan and Parsons 2018). Thus, demand for cash tends to grow with an expansion of economic activities, a decline in the opportunity cost, an intensification of precautionary motive, and other motives. "Cash hording" is defined as cash lying idle that is not being utilized for payments and thus could be driven by the opportunity cost, precautionary motive, and other motives.

A central bank normally determines the amount of cash to be issued passively by responding to changes in demand for cash. Therefore, the amount of cash in circulation mainly reflects the demand-driven factors mentioned above - rather than supply-driven or issuer-side factors - and are thus beyond the control of a central bank. A central bank issues and circulates cash through the banking system by providing commercial banks with cash demanded by withdrawing the equivalent amount from their reserve balances with a central bank; these commercial banks then distribute the acquired cash to the public on demand through windows of bank branches and/or automated teller machines (ATMs). It should be noted that the conduct of monetary policy (such as open market operations) directly influences the amount of reserve balances, not the amount of cash, although monetary policy indirectly influences cash demand through adjustment of interest rates.

The value of cash is stable in an economy where a central bank successfully conducts monetary policy in accordance with the price stability mandate (mostly, specified at around $2 \%$ in advanced economies) and thus avoids substantially high inflation or serious deflation. Most of the public do not differentiate cash and retail deposits and view them as close substitutes partly because both are denominated in the same unit of account (i.e., legal tender) and partly because providers of retail deposits are regulated by tight banking regulations and deposits are guaranteed up to the certain amount per account holder set by the deposit guarantee system in many economies.

In recent years, cashless and contractless payments methods have increasingly become prevalent in the world through various conventional tools (such as credit cards, debit cards) and innovative convenient financial services using mobile phones and smart phones. Nevertheless, cash in circulation has been rising in many economies especially after the global financial crisis. The rising trend is prevalent, even in advanced economies notwithstanding that the public normally has had full access to bank accounts and credit cards for long periods of time and other cashless and contactless payment tools in recent years. The low interest rate environment appears to have affected the rising trends. Meanwhile, emerging/developing economies continue to issue cash partly because their nominal GDP growth rates have been greater than those of advanced economies. Interestingly, some emerging economies, such as China have experienced a decline in the ratio of cash in circulation to nominal GDP. This may indicate that the Chinese have gained access to the bank accounts and/or other non-bank cashless payment and financial services.

The rising trends on cash in circulation might have several impacts on monetary policy as well as the economy. On the one hand, greater cash hoarding results in the erosion of the effectiveness of monetary policy through weakening the money creation process. On the other hand, greater cash issuance increases a central bank's income through greater seigniorage. Moreover, greater cash utilization deteriorates the efficiency in the economy owing to high cash-handling costs arising from the direct fees (i.e., cost of paper and design fees to prevent counterfeiting) and indirect cost (i.e., the security and personnel cost associated with the maintenance of cash provision and payment services by commercial banks, shops, firms, and individuals). Cash prevalence may also discourage new technology firms to enter into innovative payment and financial activities. 
This paper focuses on the movements of cash in circulation by investigating demand-driven factors contributing to the movements for the period 2000-2018. The paper covers 22 economies-eleven advanced (Australia, Canada, Denmark, the Euro Area, Japan, Korea, Norway, Singapore, Sweden, the United Kingdom, and the United States), and 11 emerging/developing economies (Brazil, China, India, Indonesia, Malaysia, Mexico, the Philippines, Poland, Russia, Thailand, and Turkey). The paper is composed of five sections. Section 2 focuses on the time-series movements of cash in circulation among 22 economies for the period 2000-2018. This paper differentiates between advanced and emerging/developing economies due to the well-developed banking system in the case of former and the presence of large unbanked population in the case of latter. Section 3 highlights the movements of banknotes in circulation differentiated by denomination in the economies whose data are available - covering Canada, the Euro Area, Japan, Korea, Poland, the United Kingdom, and the United States. Section 4 provides an empirical analysis cash demand covering all the 22 economies for the period 2000-2018. Section 5 concludes.

\section{Global Developments of Cash in Circulation}

There are various indicators tracing the movement of cash in circulation. For example, Kiaonarong and Humphrey (2019) used four indicators to measure the cash usage for payment: cash in circulation as a ratio of nominal GDP; difference between total consumption and the amount of all non-cash payment instruments used in consumption as a ratio of total consumption; the amount of cash withdrawn from ATMs and banks' windows as a ratio to total consumption; and the amount of all cash withdrawals as a ratio to cash plus the amount of non-cash payment instruments. This paper views cash in circulation as a ratio of nominal GDP as a preferred indicator to the three other indicators since the focus of this paper is cash demand driven not only by the transaction or payment motive, but also by the opportunity cost, precautionary motive, and other motives.

The 22 economies in this study are classified as either advanced economies or emerging/developing economies because the degree of the public's access to the banking system is likely to generate different impacts on cash demand depending on the stage of economic development. While bank accounts are widely available to the public in advanced economies, the public's access to bank accounts remains limited in many emerging/developing economies. The gradual decline in the unbanked population in the latter economies may promote financial inclusion and encourage the public to shift transaction or settlement instruments from cash-based to cashless-based, thereby helping to lower the ratio of cash to nominal GDP ratio. For these economies, a decline in the cash ratio may suggest higher levels of financial inclusion, strengthened financial intermediation function of the banking system, and improved monetary policy transmission mechanism. It could be also associated with greater transparency and efficiency as a result of reduced activities in the informal economy and in illegal activities. The demand for cash will be stimulated further with an increase in the ATM networks and declined charges applicable to ATM usage and cash/debit cards.

Demand for cash by households and firms is determined largely by various motives as already pointed out in the previous section. Namely, most of these motives are heavily influenced by the pace of economic activities (which heavily influence the transaction motive), interest rates (that represent opportunity cost), the occurrence of economic/financing crises (that tend to strengthen precautionary motive), and other factors such as pace of aging and safe haven demand from abroad. Generally, households are the largest holders of cash among economic entities (such as households, firms, financial institutions, and governments) because of their frequent purchases of daily goods and services with low-value banknotes. Households are often sensitive to interest rates since ordinary/checking bank accounts are a close substitute for cash, as both such bank deposits and cash serve as payment tools for daily small-value transactions payments and serve to store value.

Following households, non-financial firms are generally the second largest holder of cash. They demand cash and cash equivalents (such as checking accounts) mainly due to intensions to maintain the flexibility in their daily transactions and business decisions related to mergers and acquisitions (M\&A) and research and development $(\mathrm{R} \& \mathrm{D})$. Especially when there is information asymmetry between borrowing firms and creditors, firms with a large growth opportunity or a high external funding risk tend to maintain more liquid assets rather than using uncertain external funding (Myers and Majluf 1984). For firms, a lower interest rate promotes greater cash demand due to a decline in the opportunity cost. Nonetheless, cash holdings are likely to be dominated by households, not by firms, because households often keep cash in safety boxes due to smaller amounts of cash holdings while firms often keep money in the form of cash equivalents rather than in the form of cash itself for security reasons. For example, in the case of Japan, where the data on cash holdings by types of holders are available from the flow of funds data, households' cash holdings as of the end of 2018 accounted for $80 \%$ of total outstanding cash issued, growing steadily from 53\% in 2000. In contrast, the ratio of non-financial firms' holdings dropped from $37.5 \%$ to $8.6 \%$ over the period. Due to a lack of such detailed data decomposed by types 
of holders for other economies, this paper examines total cash in circulation without distinguishing between households and firms.

\subsection{The Case of the 11 Advanced Economies}

Figure 1(1) shows the amount of cash in circulation as a percentage of GDP and Figure 1(2) shows cash in circulation in terms of the index (by setting the amount in the first quarter of 2002 being equal to 100) for the period 2000-2018 regarding the 11 advanced economies. Charts in Appendix Figure 1 show the development of these two indicators for each economy. These figures indicate that the 11 economies can be classified into the following three types of economies with regards to the trend related to cash-nominal GDP ratio: (1) economies with a rising trend, (2) economies roughly with a stable or constant trend, and (3) economies with a declining trend.

The economies with a rising trend include the Euro Area, Japan, Korea, Singapore, the United Kingdom, and the United States. The rising trend strengthened in these economies especially after economic uncertainty rose as a result of the global financial crisis of 2008-2009. Greater political/economic/financial uncertainty tends to increase the precautionary demand for cash, reflecting diminished trust in the banking system. By contrast, the economies with a declining trend in the cash-nominal GDP ratio include Demark, Norway, and Sweden, which all have a well-developed cashless and contactless payment system. The economies with a more or less stable trend include Australia and Canada. Regarding the amount of cash in circulation, all the advanced economies except Sweden and Norway experienced a rising trend, reflecting transaction motive of cash demand. The amount of cash in circulation has grown fast in the Euro Area since the early 2000s, details of which will be discussed later. Since the global financial crisis, Korea showed a faster growth in the amount of cash in circulation. In sharp contrast, a declining trend began in Sweden from 2009 and in Norway recently from 2017.

Among the advanced economies, it is noted that Japan's cash-nominal GDP ratio has always exceeded other economies by a wide margin and has even increased to around $20 \%$ recently, further widening the gap. Japan's high cash demand may reflect that cultural habits such as high levels of public trust in the stable government and legal tender in the face of persistently-low inflation. In addition, the Bank of Japan has performed a series of unconventional monetary easing measures since the late 1990s, ranging from the zero interest rate policy in 1999-2000, to Quantitative Easing in 2001-2006, and further to Comprehensive Monetary Easing from 2010, which was then replaced in April 2013 by the Quantitative and Qualitative Monetary Easing (Shirai, 2018). Japan's intensified demand for cash in recent years might also be driven by tax-saving incentives motivated as a result of various government tax-raising measures: (a) an inheritance tax hike in January 2015; (b) an adoption of a compulsory reporting system requiring residents to submit information on detailed foreign assets to the National Tax Authority in 2014 if exceeding 50 million yen; and (c) an adoption of a compulsory reporting system requiring individuals to submit detailed information about domestic financial/non-financial assets and debts to the National Tax Authority in 2016. The government also introduced the "My Number" system in 2015, providing all the residents with an individual identification number for social security, tax payments, renumerations, financial investment, and other government records. Nonetheless, the growth rate of cash in circulation has declined recently partly due to the higher penetration of cashless payment instruments, although the cash growth rates have remained above the rates of nominal GDP growth.

In the case of the Euro Area, the circulation of euro banknotes (and coins) began at the end of 2001 and those euro banknotes (and coins) became legal tender in 2002. Demand for euro banknotes appears to have increased gradually as the public gained confidence over the common currency euro as well as monetary policy conducted by the European Central Bank (ECB), as evidenced by the steady increase in the amount of euro in circulation. ECB conducted monetary easing after the global financial crisis and a series of innovative unconventional monetary easing especially from 2014 - including negative interest rate policy, Targeted Long-term Refinancing operations (TLTRO I and II), and large-scale asset purchase program. The resultant declining interest rates made cash holding more attractive than before. ECB terminated the asset purchase program at the end of December 2018, announced a continuation of the reinvestment strategy to maintain the outstanding amount of asset holdings, and presented a plan to conduct the first hike on policy rates within 2019. However, economic slowdown in the region and declines in the rates of inflation and inflation expectation forced to the ECB to shift its monetary policy stance from a move toward normalization to a move toward accommodation since early 2019. $\mathrm{ECB}$, thus, postponed the planned timing to raise policy rates and made the decision to adopt the new TLTRO III in March 2019 with the effect from September 2019. In September 2019, furthermore, ECB reduced the negative interest rate from $-0.4 \%$ to $-0.5 \%$, and also decided to resume asset purchase program with effect from November 2019. These series of enhanced monetary easing measures may promote further demand for cash. 


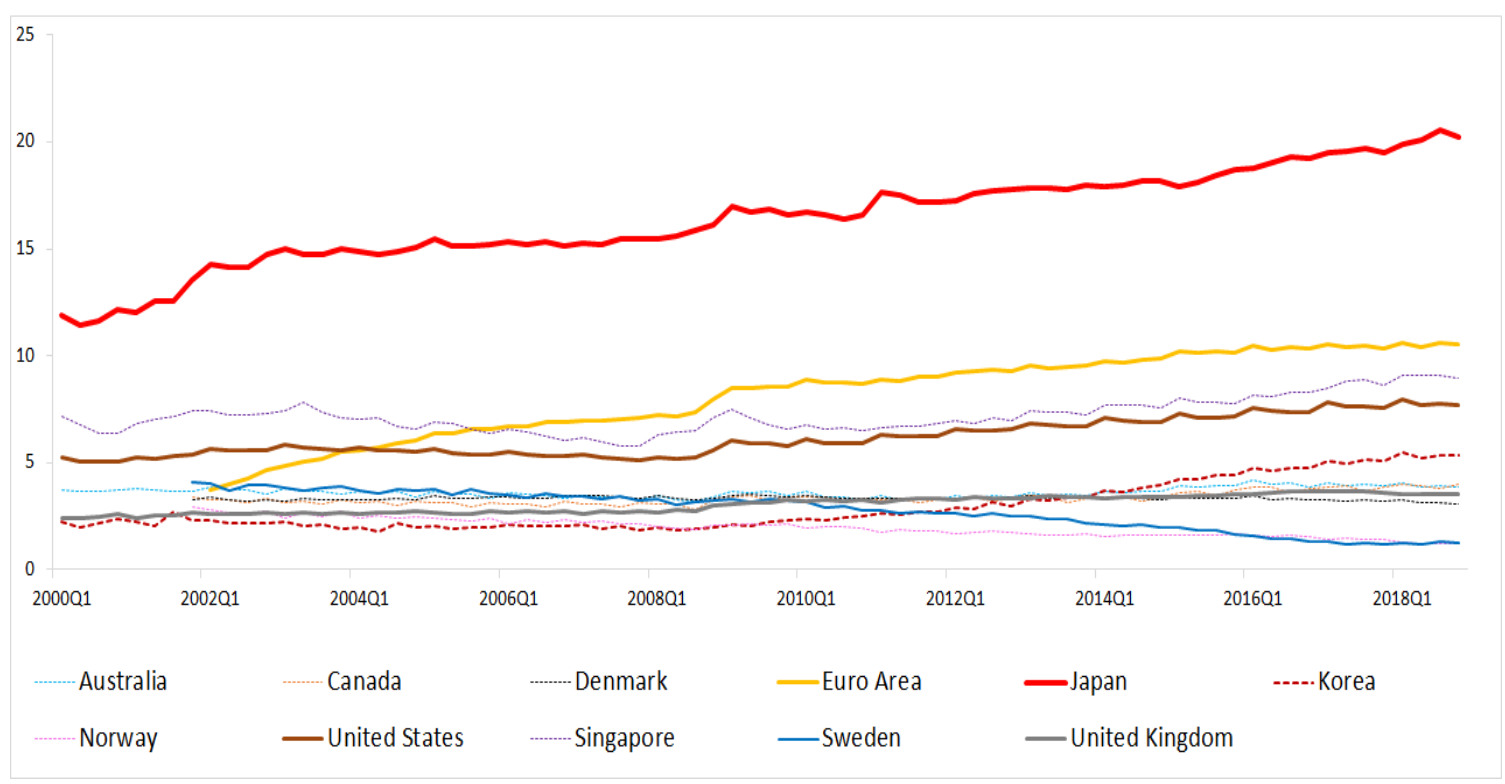

Figure 1(1). Cash in Circulation (\% of Nominal GDP) in the Advanced Economies

Source: CEIC, Bank of Canada, and Bank of England

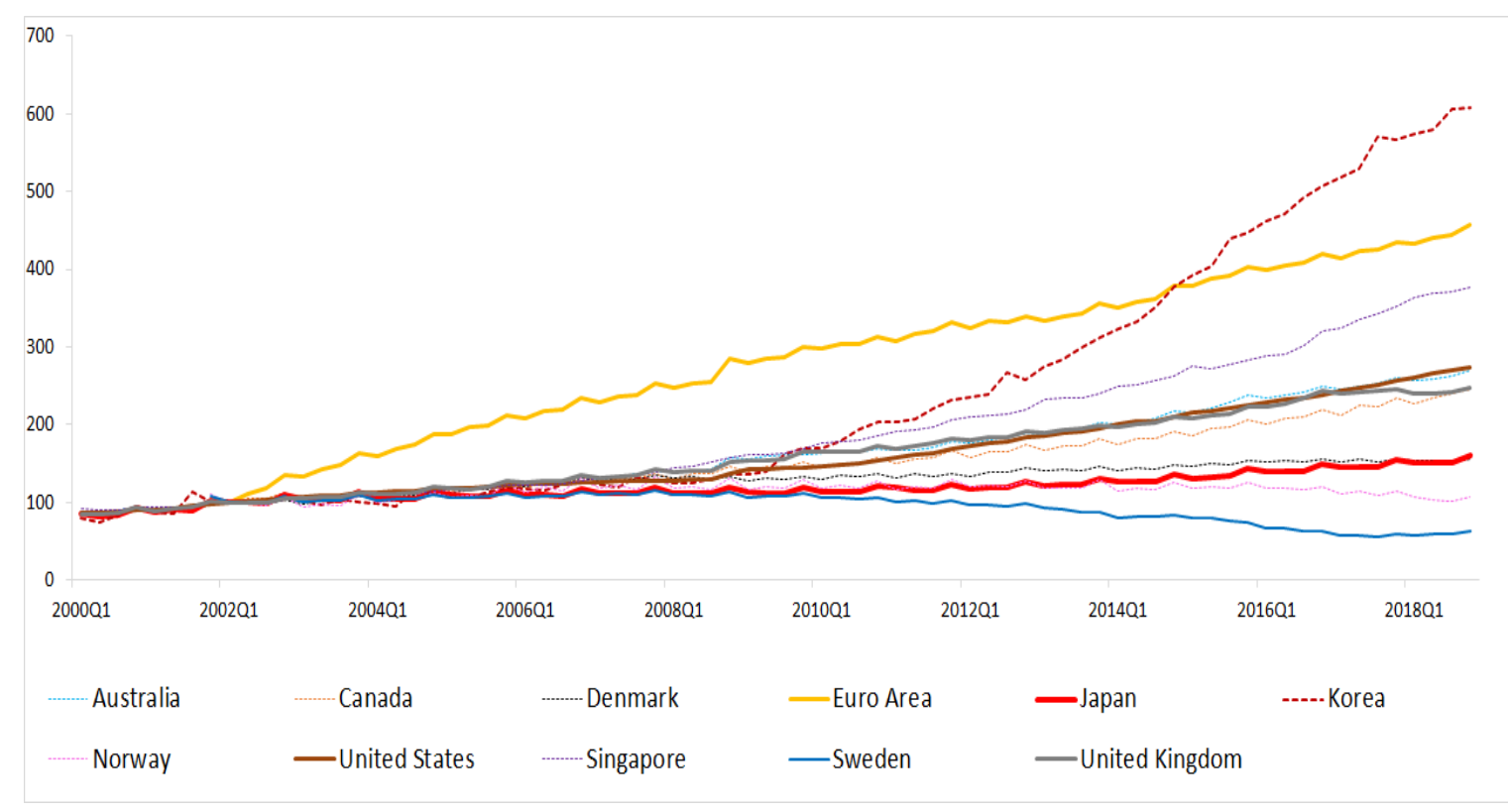

Figure 1(2). Amount of Cash in Circulation in the Advanced Economies (2002 Q1 =100)

Source: CEIC, Bank of Canada, and Bank of England

The United Kingdom has also faced a moderate increase in the ratio of cash to nominal GDP ratio even though the economy is more advanced in terms of new cashless, contactless retail payment systems compared with other advanced economies. The economy had already adopted a retail Faster Payments Scheme in 2008 as a banking sector initiative to accelerate payment times between different banks' customer accounts from three working days to a few seconds. Nevertheless, cash in circulation continues to grow in the United Kingdom. The low interest rate environment generated by the monetary easing by the Bank of England and other major central banks appear to have contributed to greater cash demand. The first quantitative easing was announced in late 2009, expanded further in 2012, and resumed in August 2016 for a short while after the surprise 23 June 2016 Brexit referendum result. Simultaneously, the Bank of England, after having maintained the policy rate at $0.5 \%$ 
from 2008, decided to lower it to $0.25 \%$ in August 2016 to cope with expected economic slowdown. Resilient economic performance subsequently led to an increase in the policy rate back to $0.5 \%$ in November 2017 and further to $0.75 \%$ in August 2018. Since early 2019, the greater concerns related to Brexit and uncertainty related to internal politics have undermined the British economy and households' and firms' sentiments. This may increase precautionary demand for cash.

In the case of the United States, the cash-nominal GDP ratio continued to rise even after the Federal Reserve increased the federal funds rate nine times from $0-0.25 \%$ to $0.25-0.5 \%$ in December 2015 to $2.25-2.5 \%$ in December 2018 in the process of monetary policy normalization. This happened even though households are using cash less frequently than the past. According to the 2018 Diary of Consumer Payment Choice by the Federal Reserve, Kumar and O'Brien (2019) found that individuals used cash in $26 \%$ of transactions (down from $30 \%$ in 2017 and $31 \%$ in 2016), while credit cards and debit cards accounted for $23 \%$ (rose from $21 \%$ in 2017 and $18 \%$ in 2016) and 28\% (rose from $26 \%$ in 2017 and 27\% in 2016), respectively. Prepaid and electronic instruments remained unpopular, accounting for only $2 \%-3 \%$ and $10 \%-11 \%$ over the same period, respectively. Surprisingly, the share of cash use among individuals under 25 years old was the highest (34\%) of any age group, slightly higher than those aged 55 years old and above. In early 2019, the Federal Reserve has shifted the monetary policy stance from normalization to an accommodative one by abruptly stopping the interest rate normalization process and advancing the timing to end the balance sheet run-off (so-called "balance sheet tightening") from the end of 2019 to the end of September 2019. In July 2019, the Federal Reserve officially ended the balance sheet runoff earlier than scheduled and cut the federal funds rate by 25 basis points from $2.25 \%-2.5 \%$ to $2 \%-2.25 \%$ for the first time since 2008 . The rate was further cut by 25 basis points in September and October 2019, reaching 1.5\%-1.75\%. These accommodation policies are expected to lead to stronger demand for cash in the economy.

In sharp contrast to Japan, the Euro Area, the United Kingdom, and the United States, Sweden exhibits a completely different pattern. Sweden progressed to become the most-advanced cashless society among the 11 advanced economies examined because of the declining trend concerning the cash-nominal GDP ratio and the amount of cash in circulation. Credit cards and a mobile-phone-based fast payment system called Swish have been widely available for some time. The pace of decline in the cash-nominal GDP ratio accelerated since 2008, which is contrary to the movements observed among other advanced economies. It should be noted that the Swedish cash-nominal GDP ratio continued to drop, even after a negative interest rate policy was adopted on the repo rate in February 2015 and was deepened gradually toward $-0.5 \%$ by February 2016 and maintained the same rate until the rate was raised to $-0.25 \%$ in January 2019 as part of monetary policy normalization. This indicates that a negative interest rate policy did not promote substitution from bank deposits to cash.

\subsection{The Case of the 11 Emerging/Developing Economies}

The cash-nominal GDP ratios and the amount of cash in circulation in the case of the 11 emerging economies/developing economies are shown in Figure 2(1) and 2(2), respectively. Charts in Appendix Figure 2 show developments with regards to the two indicators for each economy. While all the 11 economies recorded roughly a secular rising trend from early 2000s concerning the number of banknotes in circulation, divergent movements were observed with regards to the ratio of cash-nominal GDP ratios. The economies with a rising cash-nominal GDP ratio include Mexico, the Philippines, Poland, and Thailand. Their rising trend prevailed from early 2000s. The economies with the declining cash-nominal GDP ratio include China from early 2000s and Turkey since 2017. India experienced a sharp drop in the amount and the ratio in October-November 2016 due to the impact of the demonetization currency reform as mentioned below. Finally, the economies with the more or less stable cash-nominal GDP ratio include Brazil, Indonesia, Malaysia, and Russia. 


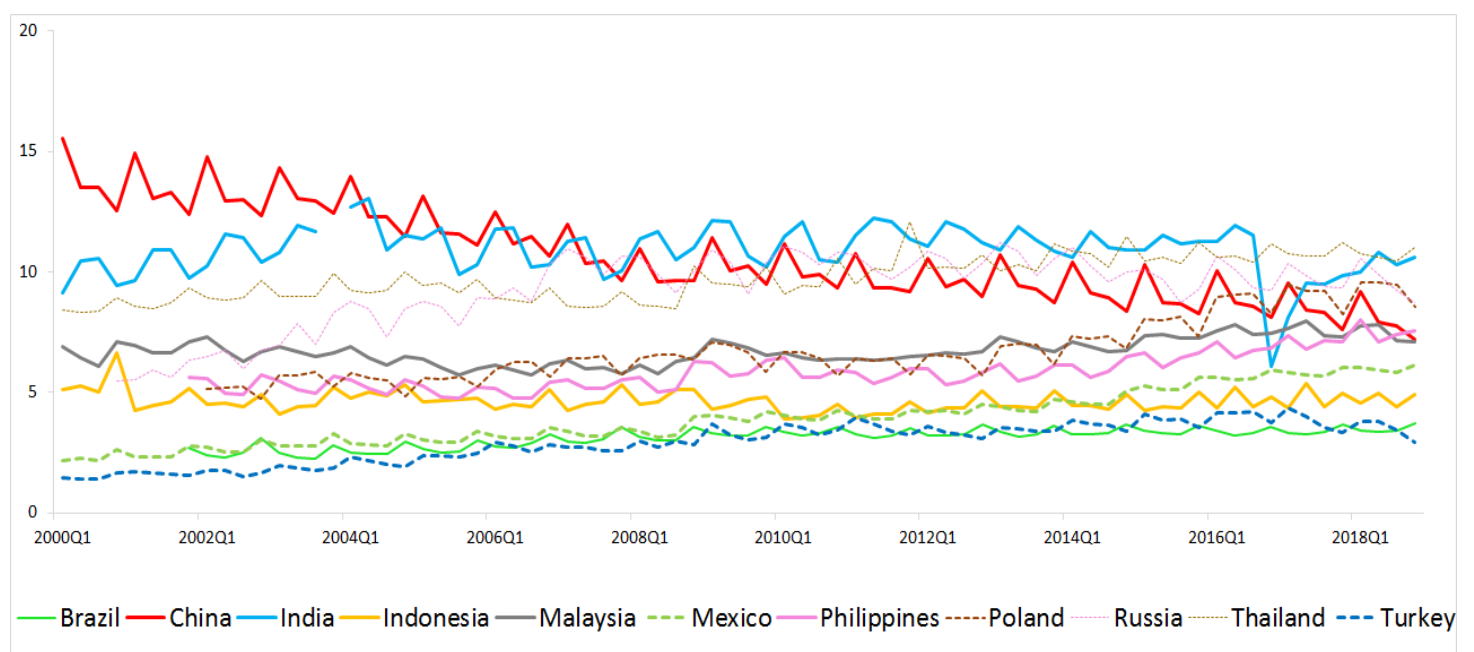

Figure 2(1). Cash (\% of Nominal GDP) in the Emerging/Developing Economies

Source: CEIC

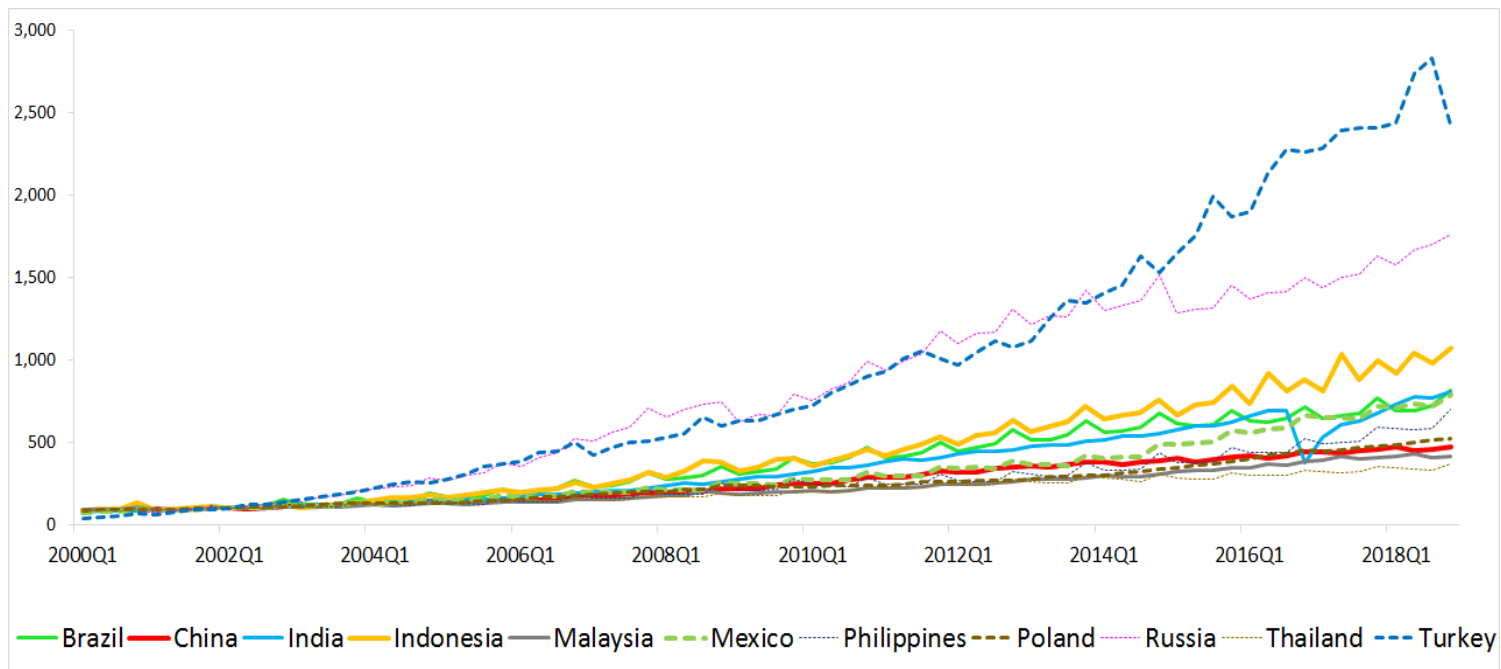

Figure 2(2). Amount of Cash in Circulation in the Emerging/Developing Economies

$$
\text { (2002 Q1=100) }
$$

Source: CEIC

In particular, a secular declining trend in the cash-nominal GDP ratio in China is noticeable. This is likely to reflect a shift in the form of money held by the public from cash to bank deposits and/or other cashless payment tools (such as Alipay or WeChat Pay). This is in line with the deepening of the banking system and an increase in the number of depositors with commercial banks. Meanwhile, India's cash-GDP ratio remained stable until the fourth quarter of 2016, suggesting that India's cash growth is associated more or less in line with transaction demand growth. A sharp drop in the ratio in India happened temporarily in 2016 after the government abruptly implemented a currency reform that triggered a temporary shortage of banknotes in circulation. India's government banned the Rs100 and Rs500 banknotes and instead introduced a new Rs500 note for the first time and issued new Rs2,000 banknotes. This currency reform was meant to fight corruption and anti-money laundering/illegal activities, but it created severe disruptions to economic activities as a result of creating serious cash shortages. While the cash ratio recovered somewhat in the following year, it appears that the ratio has been lower than the past trend, suggesting a moderate shift from cash to bank deposits or cashless payment tools.

Many emerging/developing economies have increasingly reduced cash usage for payments of goods and services 
and other transactions in recent years. This is because payment systems are currently experiencing rapid innovation and transformation with the increasing number of technology companies and financial institutions being involved as payment providers. Many governments also encourage the use of electronic payment instruments to improve efficiency in the payment systems. Nevertheless, cash demand remained strong in many economies with the exception of China.

\section{Outstanding Banknotes Issued Differentiated by Denomination in Selected Economies}

Demand for high-denomination banknotes is likely to be associated more with cash hoarding. Such demand may have become more important during the times of the global financial crisis, since concerns about the solvency of financial institutions might have prompted depositors to withdraw their funds from commercial banks or other equivalent money market funds to increase their precautionary holdings of banknotes (Cusbert and Rohling 2013). Demand for high-denomination banknotes of international reserve currency might be increased by the increased number of foreign tourists, businesspersons, and students who frequently visit the economy under investigation. High-denomination banknotes are also preferred by the people who wish to materialize flight to safety investment. Demand for higher-denomination banknotes could be associated more negatively with changes in interest rates (Arango-Arango and Suarez-Ariza, 2019). Regarding payment tools, non-cash payment tools such as credit cards are more frequently used for high-value purchases such as home electronics, furniture, expensive clothes, etc. On the other hand, low-denomination banknotes are more often used for lower-value purchases such as food and beverages. The expansion of ATM networks may increase demand for lower-denomination banknotes because of the increased frequency of trips to withdraw small numbers of banknotes.

\subsection{Economies with Greater Demand for Highest-Denomination Banknotes}

The consistent time-series data on the number of outstanding banknotes issued classified by denomination are available for seven economies - Canada, the Euro Area, Japan, Korea, Poland, the United Kingdom, and the United States. Figure 3 exhibits the annual time-series developments of outstanding banknotes issued differentiated by denomination for these economies for the period 2000-2018. These seven economies can be classified into two groups: the first group with dominant largest-denomination banknotes (Japan, Korea, and the United States) and the other group with dominant middle-denomination banknotes (Canada, the Euro Area, Poland, and the United Kingdom).

Regarding the first group, the outstanding issuance amount of the largest 10,000-yen note has always been largest over the observation period in Japan (Figure 3(1)). In addition, the pace of issuance increased further since 2013 when the Bank of Japan adopted the Quantitative and Qualitative Monetary Easing. Meanwhile, Korea began to circulate the 50,000 won in June 2009 as the largest-denomination banknote and since then the outstanding amount issued rose rapidly (Figure 3(2)). The United States experienced a rapid rise in the issuance outstanding amount concerning the $\$ 100$ note since the global financial crisis (Figure 3(3)). In both Korea and the United States, the amounts of the largest-denomination banknotes exceeded those of smaller-denomination banknotes recently. Consequently, the figures related to Japan, Korea, and the United States indicate the presence of high and rising demand for cash holdings since large-denomination banknotes are best suited for this purpose.

In the case of Japan, the dominant issuance amount of the 10,000-yen note could be attributed to the increase in cash hoarding driven by downward pressures in interest rates (and low rate of inflation even after massive monetary easing) as well as intensified tax-saving motives mentioned earlier. Otani and Suzuki (2008) estimated cash hoarding by choosing 1995 as the base year, assuming that transaction motive was present, but no cash hoarding was present, thus regarding the difference between the total 10,000-yen banknotes in circulation and that of the base year as the estimated amount of cash hoarding. Fujiki and Nakashima (2019) assumed that cash hording took place only in the form of the 10,000-yen banknote and thus estimated cash hoarding from the difference between all the units of 10,000-yen issued and the estimated transaction motive proxied by the movement of the 1,000-yen banknote (major note used in daily transactions). The paper concluded that about $40 \%$ of banknotes in circulation were attributed to cash hoardings, provided that the hoarding of 10,000 -yen banknotes began in 1995.

Regarding the United States, the rapidly rising trend of the US\$100-note issuance especially after the global financial crisis is noted. The amount of the US\$100 note issue exceeded that of the US\$20 note and all other denominates except the US\$1 note (the most frequently used note in daily transactions) in 2009 and finally exceeded even the amount of the $\$ 1$ note in 2017. There has been no sign of reversal of these trends. According to the 2017 Diary of Consumer Payment Choice (DCPC) conducted by the Federal Reserve, Greene and Stavins (2018) found that the average value of a cash transaction was only $\$ 23$, compared with $\$ 109$ for the average 
non-cash transaction (and $\$ 83$ for all transactions). From the 2018 DCPC, Kumar and O'Brien (2019) pointed out that cash represented $50 \%$ of transactions under $\$ 10$ representing and $42 \%$ of payments less than $\$ 25$. In contrast, cash is used for approximately $10 \%$ of payments $\$ 25$ and higher. This suggests that consumers evaluated cash highly for being low cost and easy to use. Cash is also an important payment option for low-income households because of the difficulty to obtain credit cards or the high annual charges associated with credit cards.

Several studies pointed out that the rising trend of US\$100 issuance is attributable not to only domestic demand but also to foreign demand, which regards the US dollar as a safe haven currency, especially from emerging/developing economies with unstable financial systems and weak macroeconomic fundamentals (Haasl, Schulhofer-Wohl, and Paulson 2018; Judson 2017). High demand for the banknotes from abroad is unique to the case of the US dollar, given the dominant status of the US dollar in various cross-border transactions. Foreign holdings of the US dollar banknotes take place through immigrants or tourists' or other cash flows especially from the United States to Mexico, as well as other commercial banking and non-banking cross-border cash transfer channels. Judson (2017) found that foreign demand for the US dollar has increased from the 1990s to early 2000s - a period that coincided with external uncertainties (such as the fall of the Berlin Wall, the collapse of the Soviet Union, and several economic and political crises in Latin America). After such demand stabilized, the global financial crisis has given rise to renewed demand for US dollar banknotes and rising demand continues until the present. Judson also estimated that such foreign demand has accounted for more than $60 \%$ of all US dollar banknotes and nearly $80 \%$ of $\$ 100$ banknotes.

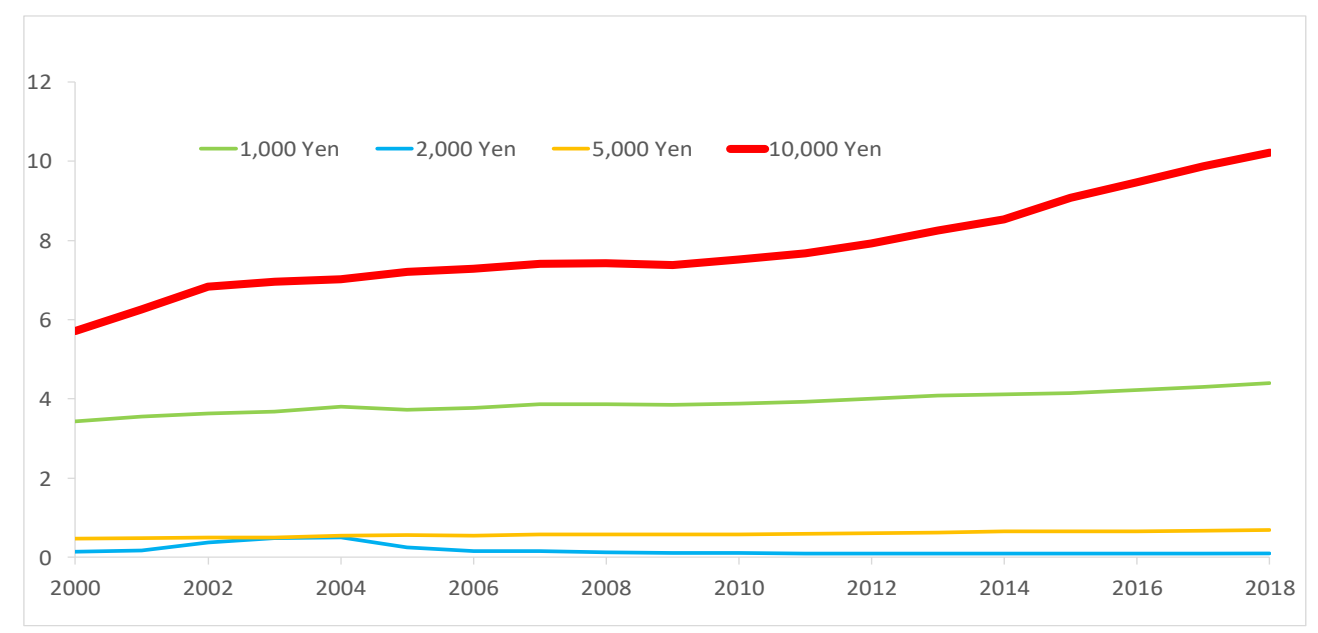

Figure 3(1). Banknotes Issued by Denomination in Japan (Unit: Billions)

Source: CEIC

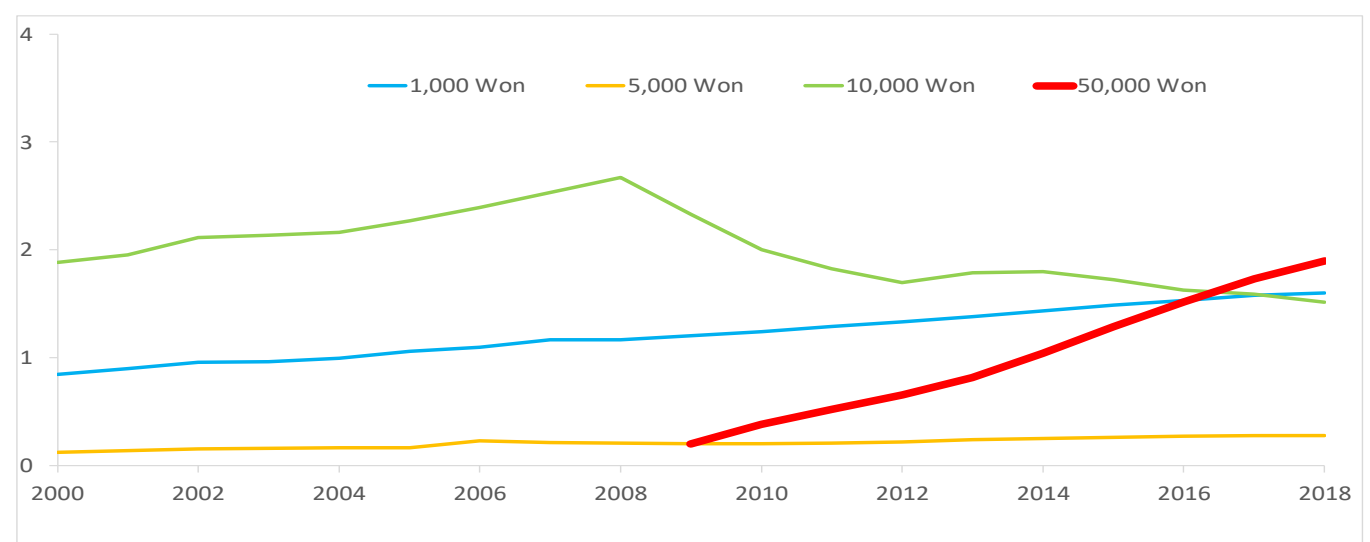

Figure 3(2). Banknotes Issued in Korea by Denomination (Unit: Billions)

Source: CEIC 


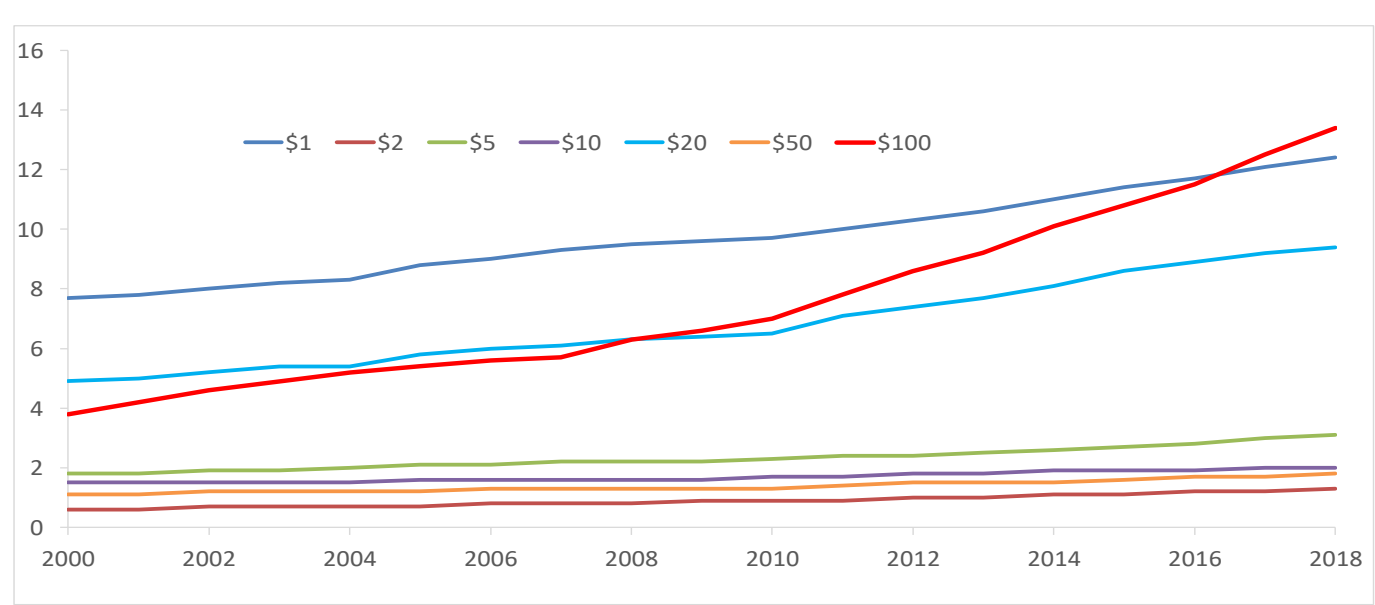

Figure 3(3). Banknotes Issued in the United States by Denomination (Unit: Billions)

Source: CEIC

\subsection{Economies with Greater Demand for Middle-Value Banknotes}

As for the second group, the outstanding amount issued over medium-denomination banknotes has dominated that of other larger-denomination and small-denomination banknotes. This is because the public use cash only for lower-value transactions and use credit cards or other cashless payment tools for higher-value transactions. For example, Canada has used the 20 Canadian dollar banknotes dominantly over the period and the gap between it and the largest-denomination (100 Canadian dollar) banknotes has remained large (Figure 3(4)). The Euro Area was dominated by the $€ 50$ banknote, followed by the $€ 20$ banknote so that the outstanding amounts issued of the $€ 500$ banknote, the $€ 200$ banknote, and the $€ 100$ banknote remained small (Figure 3(5)). In Poland, the value of outstanding issued 100 Poland zloty banknote has been dominant and has widened the gap with that of the 500 and the 200 Poland zloty banknotes (Figure 3(6)). In the United Kingdom, the outstanding amount issued on the $£ 100$ banknote has remained dominant and the gaps with the larger-denomination $£ 500$ banknote and $£ 200$ banknote have expanded over time (Figure 3(7)).

In the case of the Euro Area, the outstanding amount issued on the $€ 500$ note issued was never large as compared to other smaller-denomination banknotes such as the $€ 50$ and the $€ 20$ banknotes despite the adoption of various unconventional monetary easing tools including the large-scale asset purchase program and the negative interest rate policy. It may be related to the fact that the residents in the Euro Area maintained smaller-denomination banknotes for daily transactions and did not increase precautionary demand for cash. The ECB conducted a survey in 2016 to analyze the use of cash, cards, and other payment instruments used at points of sale (POS) by Euro Area households (Esselink and Hernández 2017). The survey results indicated that nearly two-thirds of the transactions were below $€ 15$. Moreover, two-thirds of all transactions took place in shops for purchases of day-to-day items, as well as in restaurants, bars, and cafés. On the other hand, only $8 \%$ of all transactions were above $€ 50$, and only $14 \%$ were made in shops for durable goods or in petrol stations. The report stated that access to payment cards could not be a major factor in explaining the payment behavior due to there being high access on average in the region; nevertheless, a negative relationship appeared to exist between card acceptance and cash usage. The limited usage of the $€ 500$ note indicates that the adverse impact of the ECB's decision in 2016 to stop printing the $€ 500$ note from the end of April 2019 (although continuing to circulate in the economy as legal tender) had limited impact on the economy. 


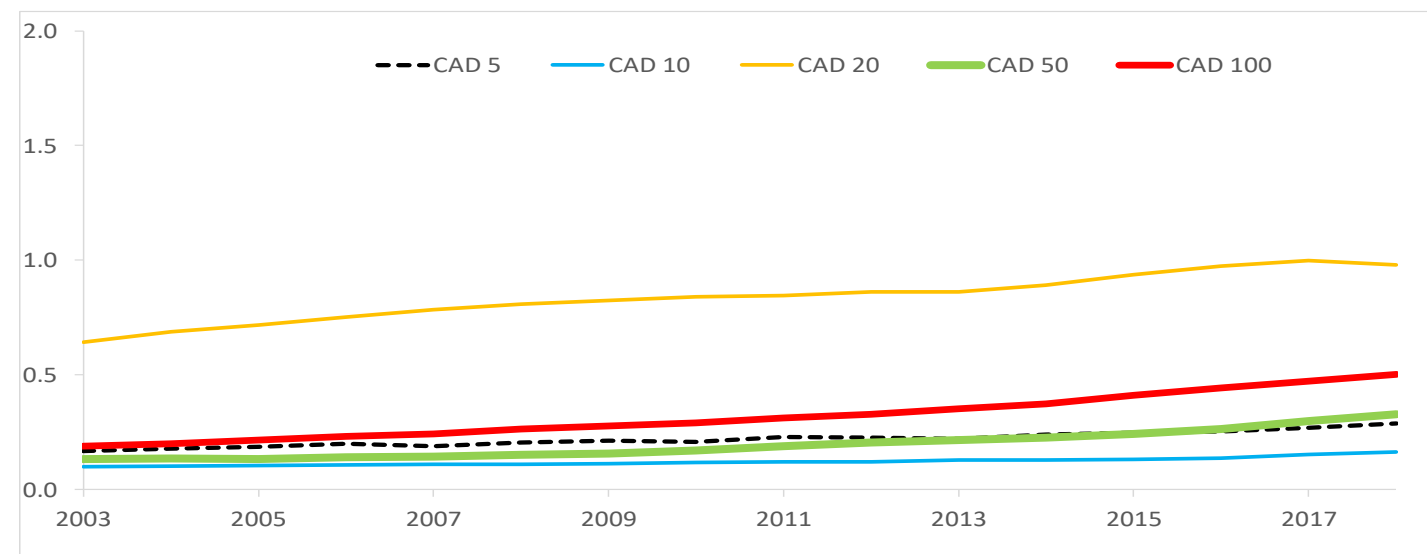

Figure 3(4). Banknotes Issued by Denomination in Canada (Unit: Billions)

Source: CEIC

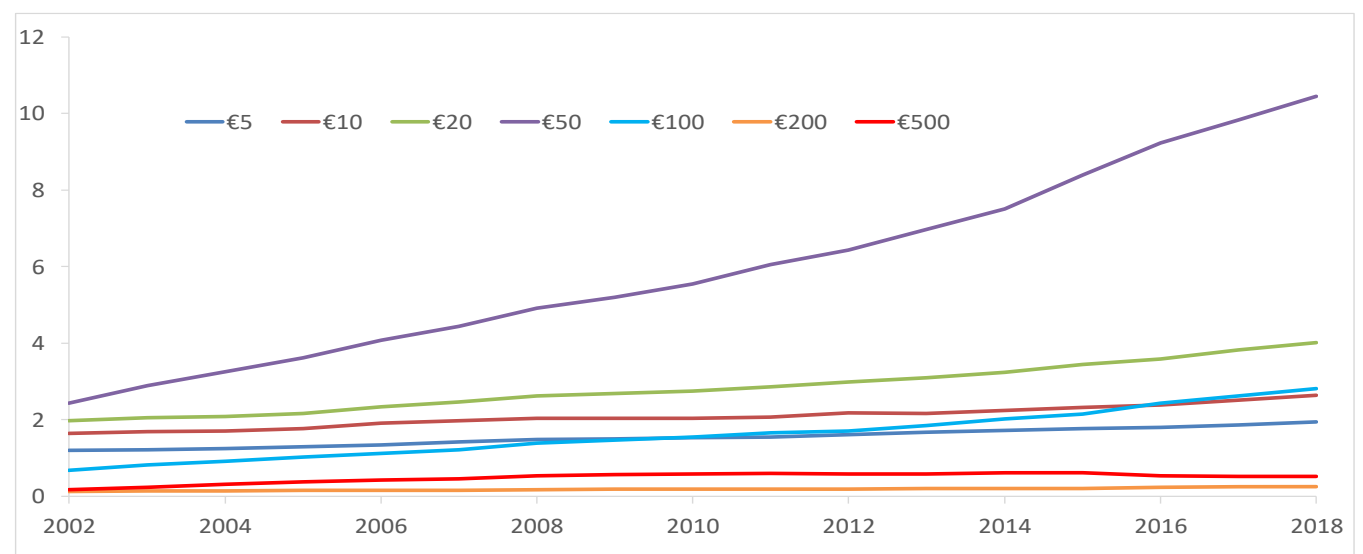

Figure 3(5). Banknotes Issued by Denomination in the Euro Area (Unit: Billions)

Source: CEIC

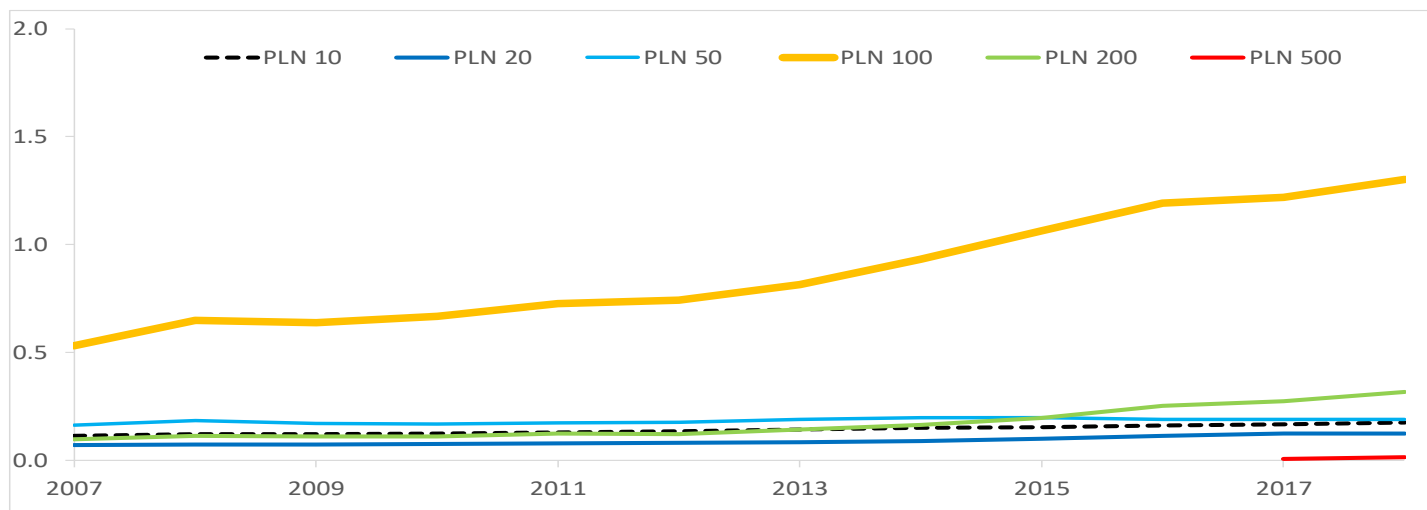

Figure 3(6). Banknotes Issued by Denomination in Poland (Unit: Billions)

Source: CEIC 


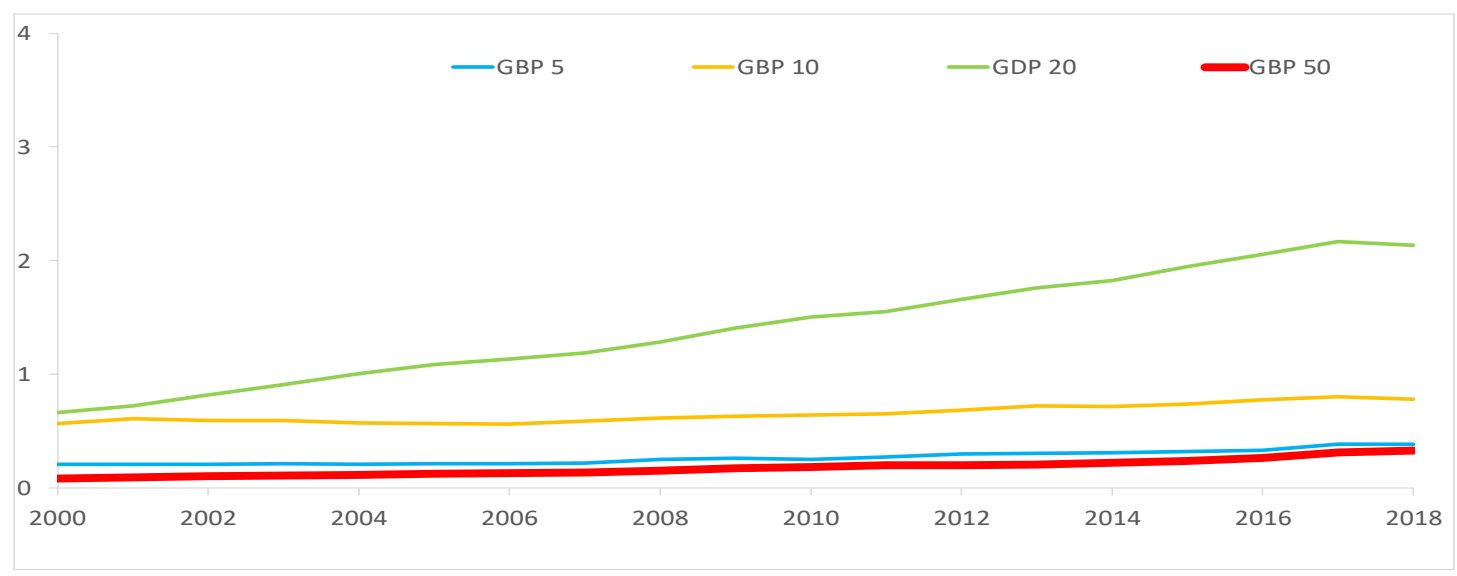

Figure 3(7). Banknotes Issued by Denomination in the United Kingdom (Unit: Billions)

Source: CEIC

\section{Empirical Analysis on Cash Demand in Advanced and Emerging/Developing Economies}

This section develops several econometric models and conducts pooled-data regressions for the 22 economies based on the following generic equation:

$$
\text { CASH }_{i, t}=\alpha+\beta_{1} \text { INTEREST }_{i, t}+\beta_{2} \text { AGE }_{i, t}+\beta_{3} \operatorname{CRISIS}_{i, t}+\varepsilon_{i, t}
$$

Cash in circulation to nominal GDP ratio for CASH is set as the dependent variable. Among independent variables, the central bank policy interest rate (INTEREST) or the yield of the benchmark 10-year yield (10-YEAR) is used to capture the opportunity cost. As for the precautionary motive, crisis dummy variable (CRISIS) is adopted, where the variable is set equal to one during the IT bubble burst in early 2000 (from the second quarter of 2000 to the third quarter of 2001) and the global financial crisis (from the second quarter of 2007 to the first quarter of 2009), and zero otherwise. As age-related factors, AGE is used interchangeably with $\log$ (LIFE). The logarithmic form is used for LIFE to enable measuring the impact of its change on the dependent variable in a percentage term. The term i refers to country index, while $t$ refers to time index. $\varepsilon_{i, t}$ refers to the error term for the respective economy. The Hausman test is conducted to select the appropriate form (between the random-effect or fixed-effect) for each model.

The signs of parameters in the model are expected to be negative for INTEREST and 10-YEAR and positive for AGE, log (LIFE), and CRISIS. An increase in the INTEREST (or the 10-YEAR) variable is expected to reduce demand for cash, as an interest rate increase implies rising opportunity cost of holding cash. The increase in the AGE (or $\log (\mathrm{LIFE})$ ) variable is expected to increase demand for cash, as the elder cohort prefer to hold cash than the younger ones due to habitual or affinity reasons. A crisis is expected to increase households' demand for cash due to precautionary reason.

Table 1 shows the results of the models with relatively good performance: Model (1), with INTEREST and AGE as independent variables; Model (2), with INTEREST and log (LIFE) as independent variables; and Model (3), with 10-YEAR and log (LIFE) as independent variables. Table 1 does not display models that incorporate the CRISIS variable, as it was not statistically significant in the models; this implies that crisis was not a major determinant for cash hoarding once covering the 22 economies in the sample.

Results from Model (1) exhibited that INTEREST and AGE were statistically significant, with a negative sign on INTEREST and a positive sign on AGE. These signs were in line with the hypotheses. This suggests that for the 22 economies combined, the central bank policy rate hike reduced demand for cash, while an increase in the ratio of elderly population increased demand for cash. Both INTEREST and log (LIFE) were statistically significant in Model (2). The parameter sign for INTEREST was negative, while positive for log (LIFE) - in line with the hypotheses. Similar to Model (1), demand for cash increased when life expectancy rose, but it fell when the policy rates increased. As proxy for opportunity cost, 10-YEAR was less robust than INTEREST as a regressor in the pooled-data models. Results from Model (3) showed that the 10-YEAR and log (LIFE) variables were statistically significant, with a negative sign for 10-YEAR and positive for log (LIFE). Yet, in the model using 10-YEAR and AGE as independent variables, it turned out that 10-YEAR was not statistically significant, while AGE remained statistically significant. 
Table 1. Pooled-Data Regression Results for the 22 Economies

(Probability of t-statistics in bracket, $*=$ significant at 5\% significance level)

\begin{tabular}{|c|c|c|c|c|c|}
\hline \multicolumn{2}{|c|}{ MODEL 1} & \multicolumn{2}{|c|}{ MODEL 2} & \multicolumn{2}{|c|}{ MODEL 3} \\
\hline Constant & $1.7877 *(0.0346)$ & Constant & $-64.4437 *(0.0000)$ & Constant & $-72.7090 *(0.0000)$ \\
\hline $\begin{array}{l}\text { INTEREST } \\
(\%)\end{array}$ & $-0.0162 *(0.0000)$ & $\begin{array}{l}\text { INTEREST } \\
(\%)\end{array}$ & $-0.0122 *(0.0000)$ & 10-YEAR (\%) & $-0.0652 *(0.0000)$ \\
\hline $\operatorname{AGE}(\%)$ & $0.3811 *(0.0000)$ & Log (LIFE) & $17.2276 *(0.0000)$ & $\log (\mathrm{LIFE})$ & $18.2785 *(0.0000)$ \\
\hline \multicolumn{2}{|c|}{ Random Effects Coefficients (Cross) } & \multicolumn{2}{|c|}{ Fixed Effects Coefficients (Cross) } & \multicolumn{2}{|c|}{ Fixed Effects Coefficients (Cross) } \\
\hline _Australia & -3.9408 & _Australia & -3.5006 & _Australia & -3.7631 \\
\hline _Canada & -4.8990 & _Canada & -3.7581 & _Canada & -4.0857 \\
\hline _Denmark & -0.6594 & _Denmark & -3.3173 & _Denmark & -3.6377 \\
\hline _Euro Area & 6.1656 & _Euro Area & 1.0526 & _Euro Area & 0.6967 \\
\hline Japan & -2.8132 & Japan & 8.7332 & Japan & 8.2646 \\
\hline _Korea & -5.6550 & _Korea & -3.9400 & _Korea & -4.2019 \\
\hline _Norway & 1.8051 & _Norway & -5.0321 & _Norway & -5.7552 \\
\hline _Singapore & -6.0034 & _Singapore & 0.0783 & _Singapore & -0.4282 \\
\hline _Sweden & -5.1291 & _Sweden & -4.2778 & _Sweden & -5.1914 \\
\hline _Utd. Kingdom & -0.6614 & _Utd. Kingdom & -3.7920 & $\begin{array}{l}\text { _Utd. } \\
\text { Kingdom }\end{array}$ & -4.0926 \\
\hline _United States & -1.0866 & _United States & -0.3497 & _United States & -0.6184 \\
\hline _Brazil & 5.6836 & _Brazil & -2.1657 & _Brazil & -1.9685 \\
\hline _China & 7.2645 & _China & 5.1633 & _China & 3.6757 \\
\hline _India & 0.9613 & _India & 7.4676 & _India & 7.5922 \\
\hline _Indonesia & 2.9679 & _Indonesia & 0.3533 & _Indonesia & 0.7204 \\
\hline _Malaysia & 0.5760 & _Malaysia & 1.0694 & _Malaysia & 0.9763 \\
\hline _Mexico & 2.5939 & _Mexico & -1.5151 & _Mexico & -1.3618 \\
\hline _Philippines & -0.3385 & _Philippines & 1.6567 & _Philippines & 1.7516 \\
\hline _Poland & 3.1243 & _Poland & 0.6448 & _Poland & 0.4499 \\
\hline _Russia & 4.6195 & _Russia & 5.3306 & _Russia & 5.5561 \\
\hline _Thailand & -1.2731 & _Thailand & 4.3703 & _Thailand & 4.1772 \\
\hline _Turkey & -1.0866 & _Turkey & -2.2893 & _Turkey & -1.9811 \\
\hline \multicolumn{6}{|c|}{ Weighted Statistics } \\
\hline$R$-squared & 0.2855 & $R$-squared & 0.9515 & $R$-squared & 0.9618 \\
\hline Adj. R-squared & 0.2845 & Adj. R-squared & 0.9506 & Adj. R-squared & 0.9611 \\
\hline $\operatorname{Prob}(F$-stats. $)$ & $0.0000^{*}$ & Prob (F-stats. $)$ & $0.0000 *$ & Prob (F-stats.) & $0.0000 *$ \\
\hline
\end{tabular}

Source: Authors' calculations

\section{Conclusion}

This paper focused on the movements of cash in circulation by investigating demand-driven factors contributing to the movements for the period 2000-2018. It focused on the time-series movements of cash in circulation (both in terms of the amount and nominal GDP) among 22 economies for the period 2000-2018. The results of the analysis can be summarized as follows:

- Among the 11 advanced economies with regards to the trend related to cash-nominal GDP ratio, there were economies with a rising trend (the Euro Area, Japan, Korea, Singapore, the United Kingdom, and the United States), economies roughly with a stable or constant trend (Australia and Canada), and economies with a 
declining trend (Demark, Norway, and Sweden). Regarding the economies with a rising trend, the rising pace accelerated especially after the economic uncertainty rose as a result of the global financial crisis of 2008-2009. As for the amount of cash in circulation, all the economies except Sweden from 2009 and Norway from 2017 showed a secular rising trend. In particular, Japan's substantially high and rising cash-nominal GDP ratio is noticeable, perhaps reflecting the public's trust in the stable government and legal tender in the face of persistently-low inflation; a limited number of crimes associated with cash handlings and counterfeiting; and, the highest proportion of the elderly in total population.

- As for the 11 emerging/developing economies, all the economies recorded the secular rising trend from early 2000s concerning the amount of cash in circulation. Some divergent movements were observed with regards to the ratio of cash-nominal GDP ratios. The economies with the rising cash-nominal GDP ratio included Mexico, the Philippines, Poland, and Thailand-all growing from early 2000s. Meanwhile, the economies with the declining cash-nominal GDP ratio included China from early 2000s and Turkey since 2017. India experienced a sharp drop in the amount and the ratio in October-November 2016 due to the impact of the demonetization currency reform. Finally, the economies with a more or less stable cash-nominal GDP ratio included Brazil, Indonesia, Malaysia, and Russia.

- With regards to the seven economies where data on banknotes in circulation differentiated by denomination are available, the economies were found to be classified into two groups: economies with dominant highest-denomination banknotes (Japan, Korea, and the United States) and economies with lower-denomination banknotes (Canada, the Euro Area, Poland, and the United Kingdom). The former group may indicate the presence of high and rising demand for cash hoarding since high-denomination banknotes are best suited for this purpose. In addition, the rising trend of the highest denomination, US $\$ 100$, could be attributable not to only domestic demand-driven factors but also to foreign demand that regards the US dollar as a safe haven currency. As for the second group, the outstanding amount issued over medium-denomination banknotes has dominated that of other higher-denomination and lower-denomination banknotes. This is because the public use cash only for lower-value transactions and use credit cards or other cashless payment tools for higher-value transactions.

- This paper found empirically that the low interest rate environment generated by massive monetary easing contributed to increasing demand for cash based on the data including advanced economies and emerging/developing economies. Age-related factors were also found to be important contributor to higher cash demand. As a future topic, it will be interesting to examine whether demand for cash will decline if stable crypto assets such as Facebook's Libra — which will stabilize the value against the basket of reputable, fiat currencies such as the US dollar- become widely used in the world.

\section{References}

Arango-Arango, C. A., \& Suarez-Ariza, N. F. (2019). Digital payments adoption and the demand for cash: New international evidence. Borradores de ECONOMIA, 1074, 1-23. Banco de la Republica de Columbia. https://doi.org/10.32468/be.1074

Cusbert, T., \& Rohling, T. (2013). Currency demand during the global financial crisis: Evidence from Australia. RBA Research Discussion Paper, RDP 2013-01, 1-33. Reserve Bank of Australia. https://doi.org/10.2139/ssrn.2209604

Esselink, H., \& Hernández, L. (2017). The use of cash by households in the Euro Area. European Central Bank Occasional Paper, 201, 1-69. European Central Bank. Retrieved from https://www.ecb.europa.eu/pub/pdf/scpops/ecb.op201.en.pdf

Flannigan, G., \& Parsons, S. (2018). High-denomination banknotes in circulation: A cross-country analysis. RBA Bulletin, March, 1-19. Reserve Bank of Australia. Retrieved from https://www.rba.gov.au/publications/bulletin/2018/mar/pdf/high-denomination-banknotes-in-circulation-a-c ross-country-analysis.pdf

Fujiki, H., \& Nakashima, K. (2019). Cash usage trends in Japan: Evidence using aggregate and household survey data. TCER Working Paper Series, E-131, 1-42. Tokyo Center for Economic Research. https://doi.org/10.2139/ssrn.3351429

Greene, C., \& Stavins, J. (2018). The 2017 diary of consumer payment choice. Federal Reserve Bank of Atlanta, Research Data Report, 18(5), 1-22. Retrieved from https://www.frbatlanta.org/-/media/documents/banking/consumer-payments/research-data-reports/2018/the2017-diary-of-consumer-payment-choice/rdr1805.pdf 
Haasl, T., Schulhofer-Wohl, S., \& Paulson, A. (2018). Understanding the demand for currency at home and abroad. Chicago Fed Letter, 396. Federal Reserve Bank of Chicago. https://doi.org/10.21033/cfl-2018-396

Judson, R. (2017). The death of cash? Not so fast: Demand for U.S. currency at home and abroad, 1990-2016. Deutsche Bundesbank International Cash Conference 2017 - War on cash: Is there a future for cash? pp. 1-33. Deutsche Bundesbank. Retrieved from https://www.econstor.eu/bitstream/10419/162910/1/Judson.pdf

Kiaonarong, T., \& Humphrey, D. (2019). Cash use across countries and the demand for central bank digital currency. IMF Working Paper, WP/19/46, 1-43. International Monetary Fund. https://doi.org/10.5089/9781484399606.001

Kumar, R., \& O’Brien, S. (2019). 2019 findings from the diary of consumer payment choice. Fed Notes, June. Federal Reserve Bank of San Francisco. Retrieved from https://www.frbsf.org/cash/publications/fed-notes/2019/june/2019-findings-from-the-diary-of-consumer-pay ment-choice/

Myers, S. C., \& Majluf, N. S. (1984). Corporate financing and investment decisions when firms have information that investors do not have. Journal of Financial Economics, 13(2), 187-221. https://doi.org/10.1016/0304-405X(84)90023-0

Otani, A., \& Suzuki, T. (2008). Background to the high level of banknotes in circulation and demand deposits. Bank of Japan Review, 2008E-5. Bank of Japan. Retrieved from https://www.boj.or.jp/en/research/wps_rev/rev_2008/data/rev08e05.pdf

Sayuri, S. (2018). Mission Incomplete: Reflating Japan's Economy (2nd ed.). Asian Development Bank Institute. Retrieved from https://www.adb.org/sites/default/files/publication/225571/adbi-mission-incomplete-reflating-japan-econom y.pdf 
APPENDIX Figure 1. Cash in Circulation in the Advanced Economies (\% of Nominal GDP, 2002 Q1=100)

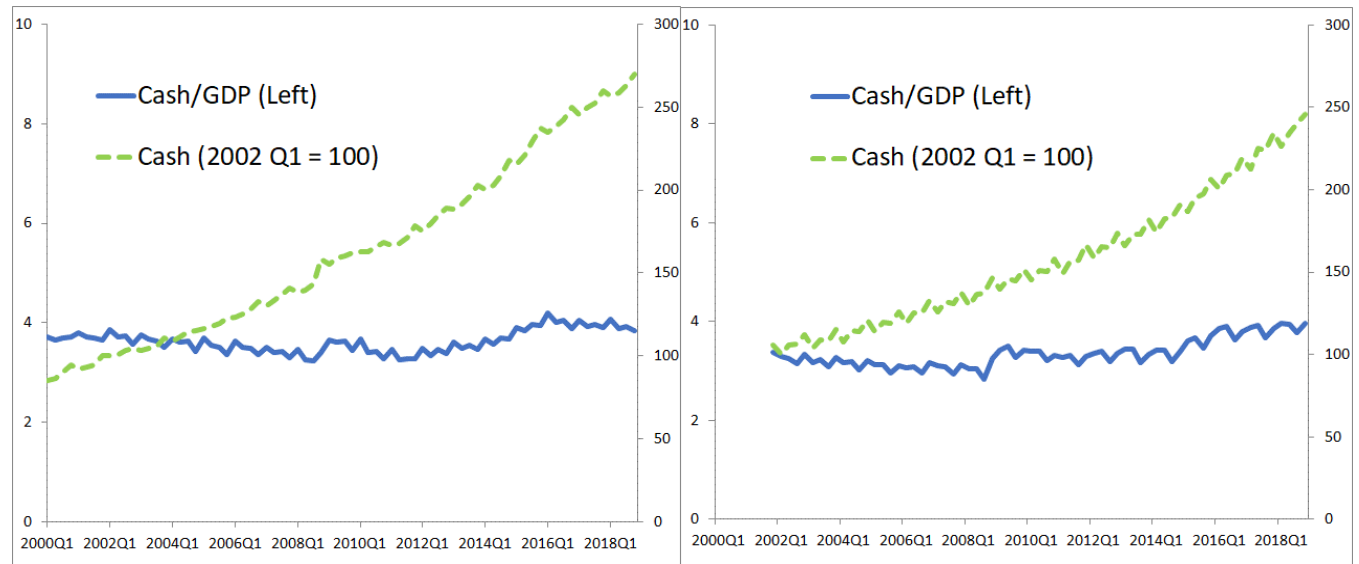

(1) Australia

(2) Canada

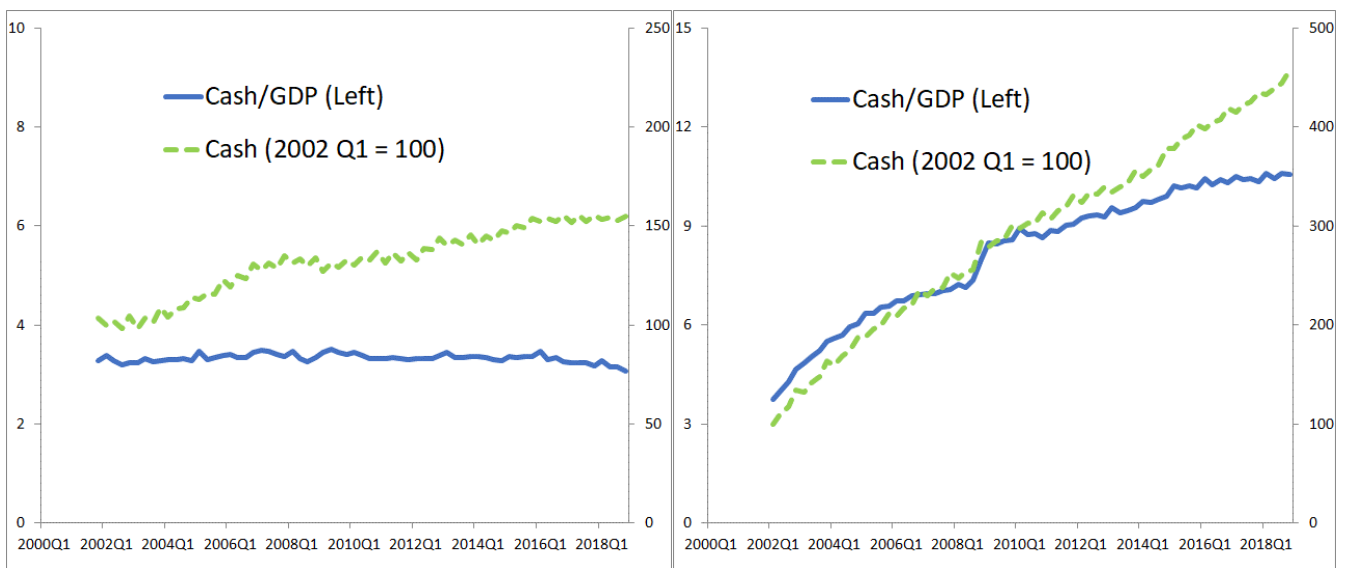

(3) Denmark

(4) Euro Area

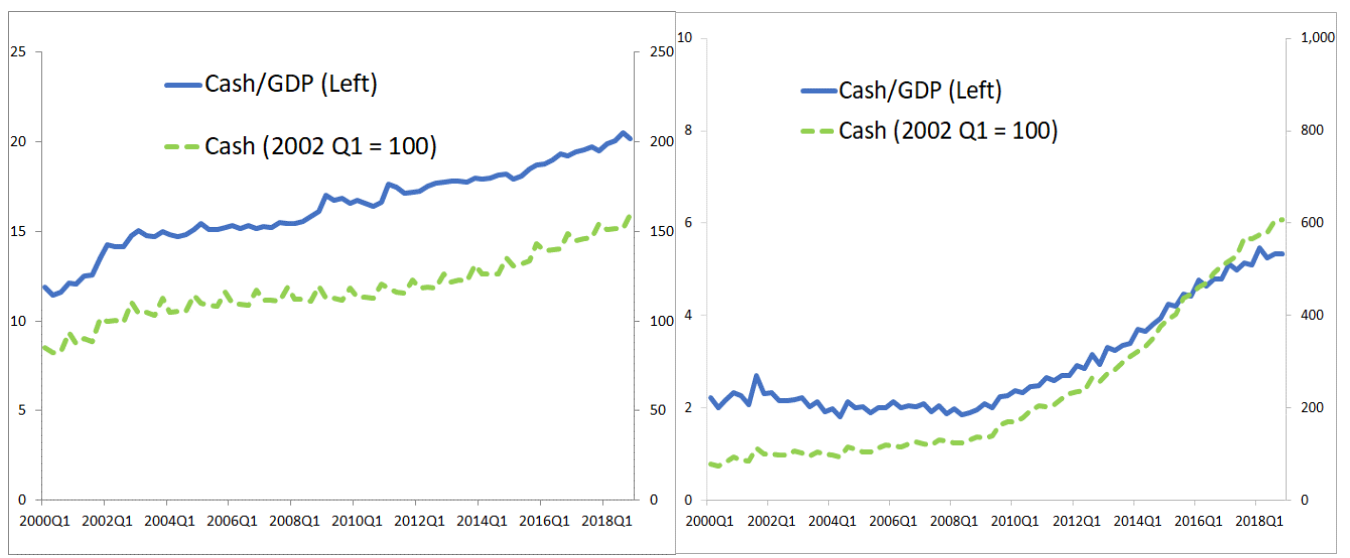

(5) Japan

(6) Korea 


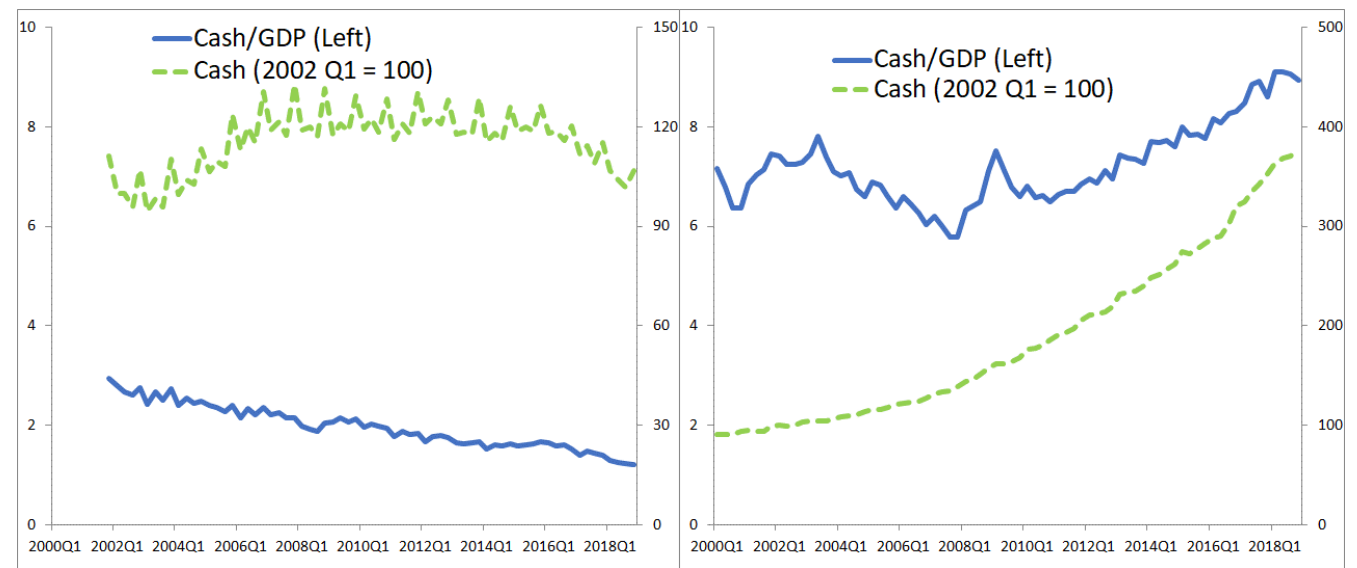

(7) Norway

(8) Singapore

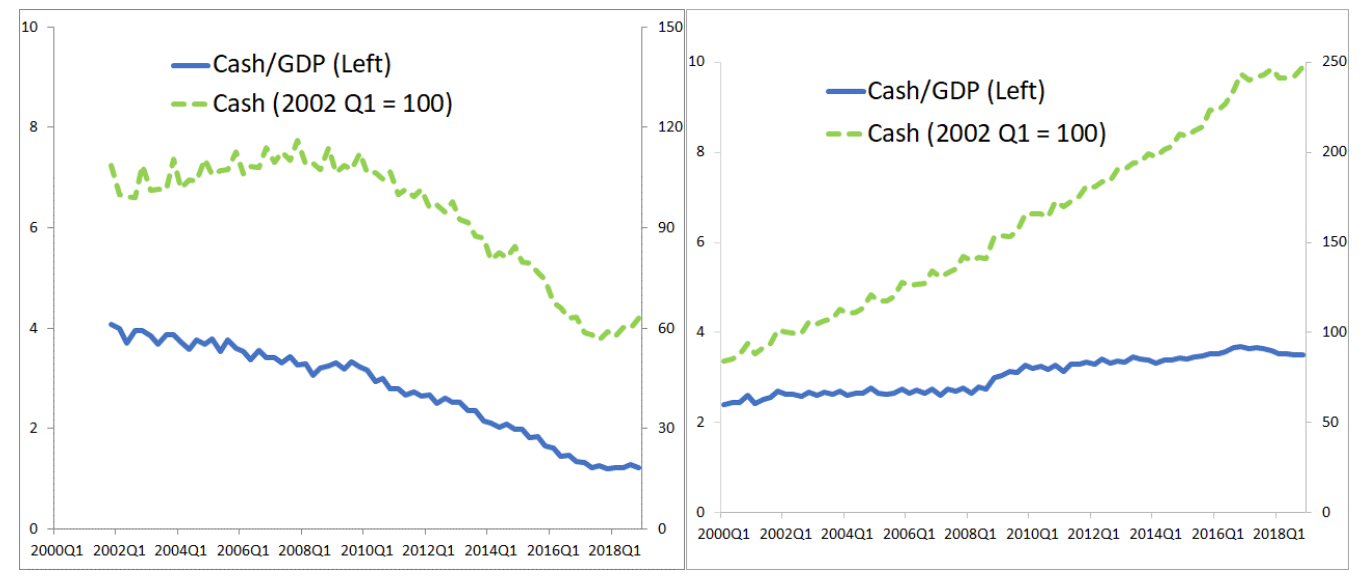

(9) Sweden

(10) United Kingdom

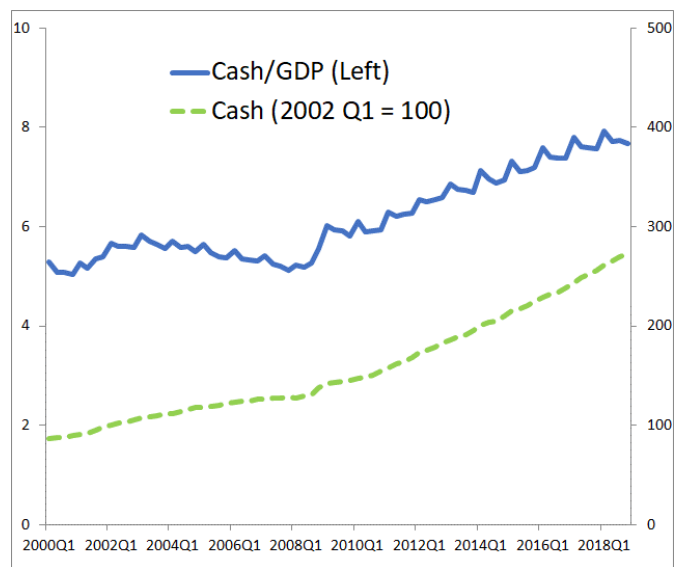

(11) United States

Source: CEIC 
APPENDIX Figure 2. Cash in Circulation in the Emerging/Developing Economies (\% of Nominal GDP, 2002 $\mathrm{Q} 1=100)$

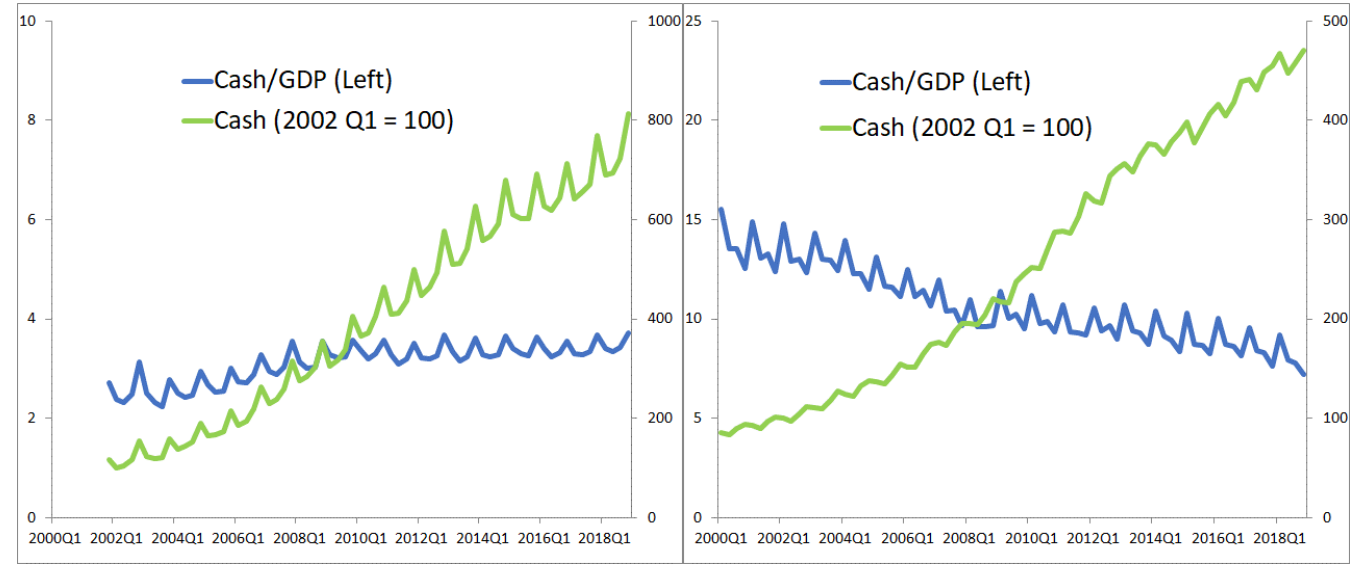

(1) Brazil

(2) China

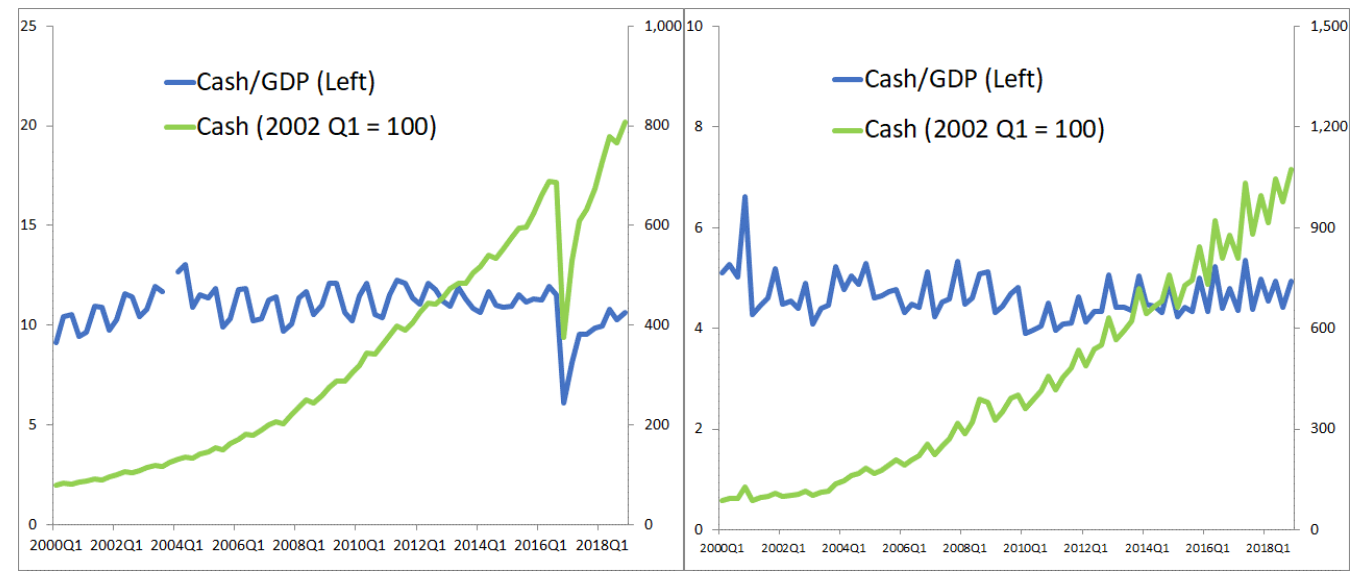

(3) India

(4) Indonesia

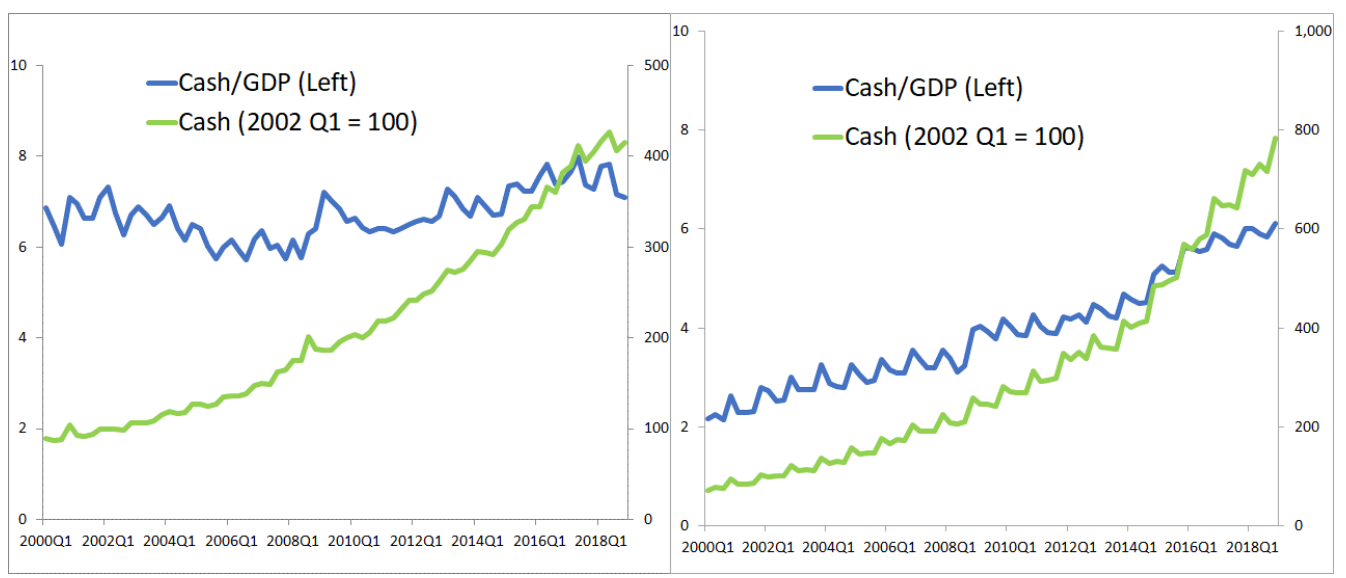

(5) Malaysia

(6) Mexico 


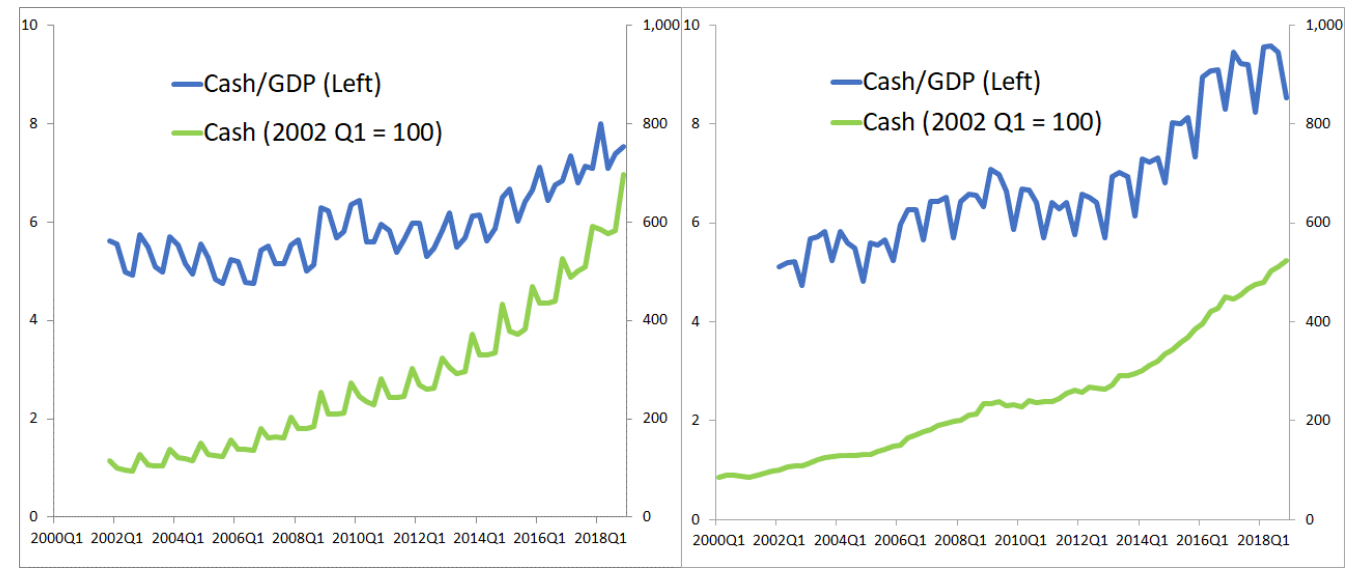

(7) Philippines

(8) Poland

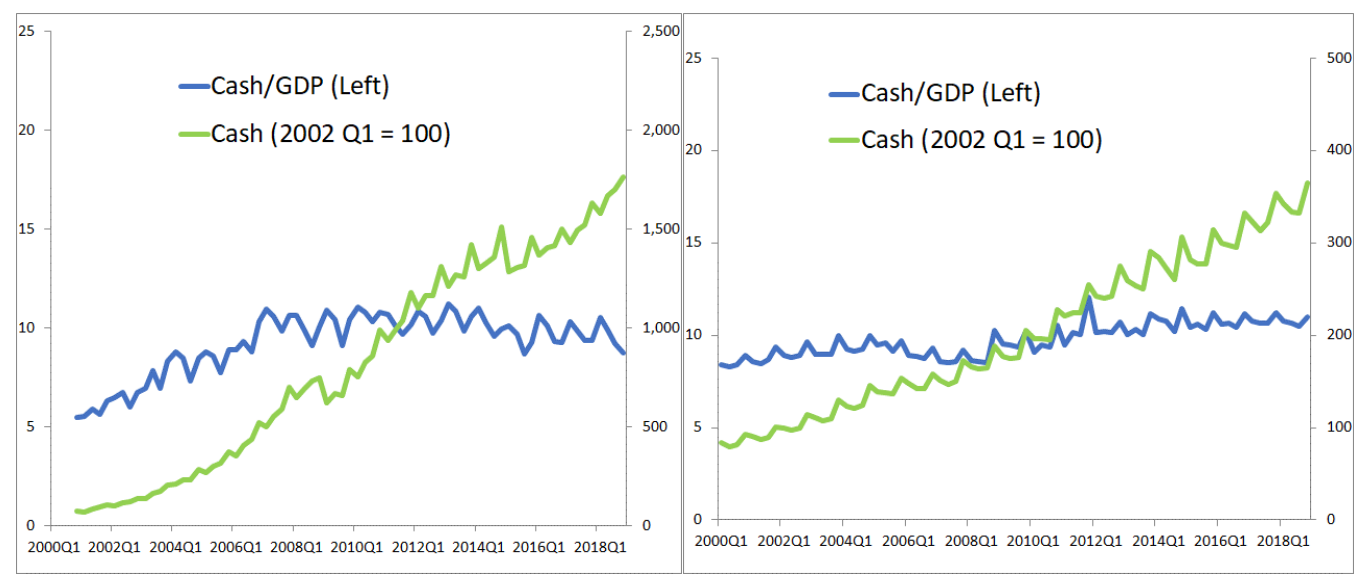

(9) Russia

(10) Thailand

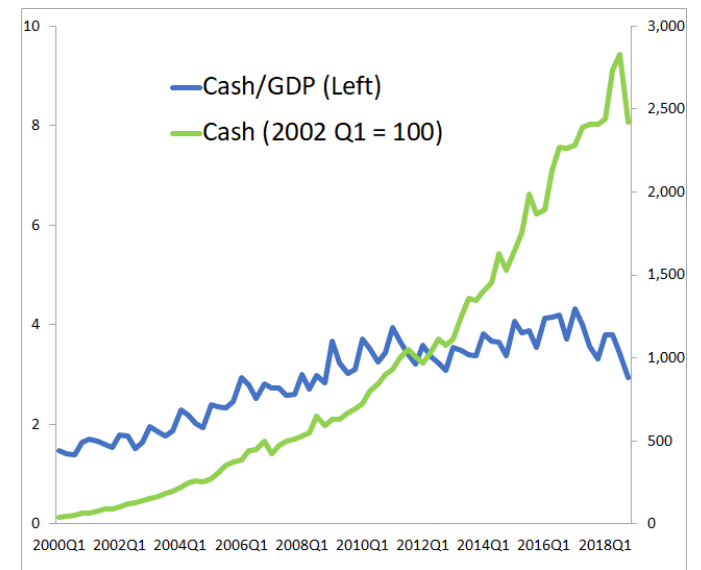

(11) Turkey

Source: CEIC

\section{Copyrights}

Copyright for this article is retained by the author(s), with first publication rights granted to the journal.

This is an open-access article distributed under the terms and conditions of the Creative Commons Attribution license (http://creativecommons.org/licenses/by/4.0/). 